\title{
Dose Pack
}

National Cancer Institute

\section{Source}

National Cancer Institute. Dose Pack. NCI Thesaurus. Code C43192.

A container in which a preselected dose or dose regimen of the medication is placed. 